\title{
PENGARUH PERSEPSI HARGA DAN CITRA MEREK TERHADAP MINAT BELI PRODUK MOTOR MEREK YAMAHA NMAX DI KOTA PALU
}

\author{
Eka Desyani \\ Wahyuningsih \\ Ponirin \\ Jurusan Manajemen, Fakultas Ekonomi, Universitas Tadulako \\ email: dessymakarau@gmail.com
}

\begin{abstract}
This study aims to determine the influence of price perceptions and brand image on the interest in purchasing Yamaha NMAX in Palu City. Type of stduy is explanatory. Population consist of people in Palu City who have known and interested, but do not yet have Yamaha NMAX products. Sampling technique is purposive sampling, with total samples of 90 people. Data collection using questionnaire which then processed by using regression analysis tool with SPSS for Windows Release 16.0. Method of analysis is multiple regression analysis. The result shows that price perceptions have positive and significant influence on the interest of poeople purchasing Yamaha NMAX in Palu City, with significance level $t$-sig. of $(0,05 \geq 0.041)$ with regression coefficient equals to 0.154 . Brand image has positive and significant influence on the interest of buying Yamaha NMAX in Palu City, with significance level $t$ sig. of $(0,05 \geq 0.000)$ with regression coefficient value equals to 0.464 .
\end{abstract}

Keywords: price perception, brand image, purchase interest.

\begin{abstract}
ABSTRAK
Penelitian ini bertujuan untuk mengetahui pengaruh persepsi harga dan citra merek terhadap minat beli produk motor merek Yamaha NMAX Di kota Palu. Jenis penelitian yang digunakan adalah eksplanatory research (penelitian penjelasan). Populasi dalam penelitian ini dikhususkan pada masyarakat kota Palu yang mengetahui dan berminat, tetapi belum memiliki produk Yamaha NMAX. Teknik penarikan sampel dalam penelitian ini adalah purposive sampling, dengan jumlah sampel sebanyak 90 responden. Pengambilan data menggunakan kuesioner yang kemudian diolah dengan menggunakan alat analisis regresi dengan program SPSS For Windows Release 16.0. Metode analisis yang digunakan dalam penelitian ini ialah analisis regresi berganda. Hasil pengujian menunjukkan bahwa variabel persepsi harga berpengaruh positif dan signifikan terhadap minat beli produk motor merek Yamaha NMAX di kota Palu, dengan tingkat signifikansi t sig. $(0,05 \geq 0,041)$ dengan nilai koefisien regresi sebesar 0,154 . Variabel citra merek berpengaruh positif dan signifikan terhadap minat beli produk motor merek Yamaha NMAX di kota Palu, dengan tingkat signifikansi t sig. $(0,05 \geq$ $0,000)$ dengan nilai koefisien regresi sebesar 0,464.
\end{abstract}

Kata Kunci: Persepsi Harga, Citra Merek, Minat Beli.

\section{PENDAHULUAN}

Perkembangan dan pertumbuhan industri otomotif khususnya sepeda motor saat ini sangatlah pesat. Hal ini ditandai dengan terus bertambahnya kuantitas kendaraan sepeda motor yang dimiliki oleh masyarakat. Sepeda motor merupakan alat transportasi alternatif untuk bepergian secara mudah, irit bahan bakar dan terjangkau oleh berbagai kalangan masyarakat. Masyarakat memilih sepeda motor dengan alasan sepeda motor adalah kendaraan yang praktis untuk bepergian, khususnya di kawasan perkotaan untuk menghindari kemacetan. Jumlah kendaraan sepeda motor di Indonesia pun lebih banyak dibandingkan dengan kendaraan lain. Korps Lalu Lintas Kepolisian Negara Republik Indonesia menyatakan populasi kendaraan terbanyak adalah sepeda motor dengan jumlah 86.253 juta unit. Jumlah terbesar selanjutnya adalah mobil penumpang tercatat 10,54 juta unit, mobil barang (truk, pick up dan lainnya) tercatat 5,156 juta unit, dan kendaraan khusus tercatat 297.656 unit.

Penjualan sepeda motor matic di Indonesia semakin meningkat dari tahun 2016 walaupun berada di tengah tekanan berbagai tantangan seperti kenaikan harga bahan bakar minyak, persaingan antar 
Desyani, E.

perusahaan motor yang ketat, serta pembatasan jumlah kepemilikan kendaraan bermotor lewat pajak progresif. Seperti yang dilansir dari Kompas Otomotif, penjualan sepeda motor tanah air pada pembukaan tahun (Januari 2017) menunjukkan hasil positif, naik 13,84 persen menjadi 473.879 unit dari tahun 2016. Walaupun demikian, angka ini belum melampaui pencapaian pada 2015, yang sebanyak 502.783. Kondisi ini membuat para produsen sepeda motor yang tergabung dalam Asosiasi Industri Sepeda Motor Indonesia (AISI) menjadi optimis mampu meningkatkan penjualan dari tahun ke tahun.

Industri sepeda motor matic menunjukkan persaingan yang sangat ketat. Ketatnya persaingan pada jenis kendaraan sepeda motor membuat para produsen berlomba-lomba melakukan inovasi pada atribut-atribut yang melekat pada produknya untuk merebut pangsa pasar. Banyak produsen dari berbagai merek sepeda motor menawarkan tipe, model, dan spesifikasi yang bersaing agar menarik minat beli konsumen.

Pasar otomotif dalam segmentasi motor skuter matic kelas $150 \mathrm{cc}$ pada awalnya dikuasai Honda PCX. Tetapi fakta tersebut tidak mampu membuat Honda tenang dan melenggang sendirian. Yamaha yang merupakan produsen motor satu negara dengan Honda juga menciptakan skuter matic premium kelas $150 \mathrm{cc}$ terbaru yang diberi nama Yamaha NMAX. Peluncuran skuter matic Yamaha ini dilaksanakan pada 23 Januari 2015. Sedangkan untuk perilisan Yamaha NMAX secara resmi oleh YIMM (Yamaha Indonesia Motor Manufacturing) dilaksanakan pada bulan Februari 2015. NMAX diperkenalkan sebagai anggota terbaru dari seri MAX, yaitu NMAX, XMAX dan TMAX yang merupakan jajaran maksi-skuter sporty dari Yamaha. Harga Yamaha NMAX dibanderol dengan Rp. 27.900.000,00 untuk versi ABS (Anti-Lock Brake System), sedangkan untuk harga Yamaha NMAX Non ABS dipasarkan lebih murah yaitu Rp. 23.500.000,00.

Harga Yamaha NMAX jauh lebih murah dari Honda PCX yang dibanderol Rp.39.800.00,00, namun, kedua perusahaan mengatakan bahwa dua model ini berada di segmen berbeda, namun jika melihat fitur dan keunggulan masing-masing, mereka tetaplah kompetitor. Penetapan harga yang jauh lebih murah, Yamaha NMAX memiliki keunggulan yang tidak kalah bersaing dengan Honda PCX. Menurut Kompas Otomotif, Yamaha NMAX juga masuk dalam daftar 20 sepeda motor terlaris tahun 2017 urutan ke-6, sedangkan Honda PCX tidak termasuk.

Penjualan di seluruh Indonesia Yamaha NMAX berada di posisi ke-6, namun di kota Palu penjualan Yamaha NMAX masih terbilang rendah yaitu untuk tipe ABS hanya terjual $40 \%$ dari target, sedangkan untuk tipe None-ABS hanya terjual 50\% dari target setiap bulannya. Adapun jumlah penjualan Yamaha NMAX rata-rata per bulan di kota Palu berdasarkan salah satu dealer Yamaha terbesar di Sulawesi Tengah, Akai Jaya Motor adalah sebagai berikut:

Tabel 1 Penjualan Yamaha NMAX Rata-Rata Per Bulan di Kota Palu

\begin{tabular}{|l|c|c|}
\hline \multicolumn{1}{|c|}{ Tipe } & $\begin{array}{c}\text { Target Penjualan } \\
\text { (Unit) }\end{array}$ & $\begin{array}{c}\text { Jumlah Penjualan } \\
\text { (Unit) }\end{array}$ \\
\hline Anti-Lock Brake System (ABS) & 72 & $25(40 \%)$ \\
\hline None Anti-Lock Brake System (NON ABS) & 80 & $40(50 \%)$ \\
\hline
\end{tabular}

Sumber: Akai Jaya Motor Palu.

Tinggi atau rendahnya harga suatu barang tergantung dari persepsi masing-masing konsumen. Menurut Schiffman dan Kanuk (2004:186) persepsi harga adalah bagaimana pelanggan memandang harga tertentu (tinggi, rendah, wajar) yang berpengaruh kuat terhadap maksud membeli dan kepuasan membeli. Berdasarkan pra penelitian, beberapa konsumen menganggap bahwa harga Yamaha NMAX masih terlalu mahal untuk jenis motor matic. Sedangkan beberapa konsumen lainnya berpendapat bahwa harga yang tinggi dari Yamaha NMAX mencerminkan bahwa Yamaha NMAX lebih berkelas dengan kualitas dan spesifikasi yang lebih baik dibandingkan motor matic dengan harga lebih rendah. 
Tidak hanya mengenai bagaimana konsumen memandang harga suatu produk, citra merek juga dianggap sebagai pilar bisnis sehingga dapat menarik minat konsumen untuk memakai produk tersebut. Merek merupakan salah satu pertimbangan konsumen untuk menggunakan suatu produk. Perusahaan yang berhasil membangun merek yang kuat akan memiliki nilai tambah yang lebih dari perusahaan lain. Tjiptono (2011:112) mendefinisikan citra merek yakni deskripsi tentang asosiasi dan keyakinan konsumen terhadap merek tertentu.

Minat beli merupakan tahap kecenderungan konsumen untuk bertindak sebelum keputusan membeli benar-benar dilaksanakan. Terdapat perbedaan antara pembelian aktual dan minat pembelian. Bila pembelian aktual adalah pembelian yang benar-benar dilakukan oleh konsumen, maka minat pembelian adalah niat untuk melakukan pembelian pada kesempatan mendatang (Kinnear dan Taylor dalam Bachriansyah, 2011). Penetapan harga yang sesuai dengan kualitas produk serta citra merek yang baik yang telah tercermin dari produk-produk Yamaha diharapkan dapat menciptakan sebuah perilaku konsumen yang nantinya dapat menimbulkan sebuah minat konsumen untuk membeli produknya.

Berdasarkan uraian permasalahan tersebut, maka tujuan dari penelitian adalah untuk menganalisis pengaruh persepsi harga terhadap minat beli produk motor merek Yamaha NMAX di Kota Palu, untuk menganalisis pengaruh citra merek terhadap minat beli produk motor merek Yamaha NMAX di Kota Palu, serta untuk menganalisis pengaruh persepsi harga dan citra merek terhadap minat beli produk motor merek Yamaha NMAX di Kota Palu.

\section{KAJIAN LITERATURE DAN PENGEMBANGAN HIPOTESIS Persepsi Harga}

Simamora (2002:102) mendefinisikan persepsi adalah "bagaimana kita melihat dunia sekitar kita" atau secara formal, merupakan suatu proses dengan mana seseorang menyeleksi, mengorganisasikan, dan menginterpretasi stimulus ke dalam suatu gambaran dunia yang berarti dan menyeluruh. Menurut Mowen dalam Sumarwan (2003:70) bahwa persepsi adalah proses di mana individu-individu menggali informasi, memperhatikan informasi itu, dan memahaminya.

Menurut Monroe dalam Harjanti dan Venesia (2015:67) persepsi pada dasarnya melibatkan proses kategorisasi, yaitu kita cenderung untuk untuk menempatkan pengalaman yang baru ke dalam klasifikasi yang ada dalam pengalaman yang sudah familiar. Solomon (2007:49) berpendapat persepsi adalah proses di mana orang memilih, mengatur dan menafsirkan manfaat, kemudian, berfokus pada apa yang kita perbuat dalam menambahkan sesuatu yang mentah untuk memberi mereka makna.

Schiffman dan Kanuk (2004:186) mengatakan bahwa persepsi harga adalah bagaimana pelanggan memandang harga tertentu (tinggi, rendah, wajar) yang berpengaruh kuat terhadap maksud membeli dan kepuasan membeli. Menurut Peter dan Olson (2010:447) persepsi harga adalah bagaimana informasi harga dapat dipahami oleh pelanggan dan membuat berarti bagi pelanggan. Malik dan Yaqoob (2012: 487) mengatakan bahwa persepsi harga adalah sebuah proses di mana pelanggan menafsirkan nilai harga dan atribut ke barang atau pelayanan yang diinginkan.

Persepsi harga sering diidentikkan dengan persepsi kualitas dan persepsi biaya yang dikeluarkan untuk memperoleh produk (Monroe dalam Harjanti dan Venesia, 2015:67). Informasi harga aktual yang diperoleh akan dibandingkan dengan persepsi harga yang ada di benak pelanggan. Hal ini mengindikasikan persepsi nilai terhadap produk atau pelayanan tersebut. Selanjutnya pelanggan akan memutuskan, apakah akan membeli produk/pelayanan tersebut atau tidak. Persepsi harga dibentuk oleh dua dimensi utama yaitu:

1. Perceived Quality (Persepsi Kualitas): Pelanggan cenderung lebih menyukai produk yang harganya mahal ketika informasi yang didapat hanya harga produknya. Persepsi pelanggan terhadap kualitas suatu produk dipengaruhi oleh persepsi mereka terhadap nama merek, nama toko, garansi yang diberikan (after sale services) dan negara yang menghasilkan produk tersebut. 
Desyani, E.

2. Perceived Monetary Sacrifice (Persepsi Biaya yang Dikeluarkan): Secara umum pelanggan menganggap bahwa harga merupakan biaya yang dikeluarkan atau dikorbankan untuk mendapatkan produk. Akan tetapi pelanggan mempunyai persepsi yang berbeda-beda terhadap biaya yang dikeluarkan meskipun untuk produk yang sama.

Kotler dan Amstrong dalam Selang (2013:75) menyatakan indikator harga antara lain keterjangkauan harga produk, kesesuaian harga dengan kualitas produk dan kesesuaian harga dengan manfaat. Sedangkan menurut Alma (2010:178), adakalanya konsumen tidak peka atau tidak peduli dengan perbedaan harga yang dilancarkan oleh produsen, walaupun harga mahal namun konsumen tetap bersedia membayarnya. Hal ini terjadi karena berbagai alasan seperti:

1. Barangnya unik, langka, bergengsi mempunyai nilai seni tertentu yang diminati oleh orang-orang tertentu pula.

2. Produk tersebut tidak ada penggantinya.

3. Konsumennya adalah orang-orang berpenghasilan tinggi atau dalam membeli produk tersebut akan menciptakan suatu prestise.

4. Harga beli barang tersebut dibayarkan oleh orang lain, sehingga konsumen dapat membeli barangbarang yang harganya mahal.

5. Penggunaan produk merupakan pelengkap barang yang sudah dibeli sebelumnya.

6. Persediaan barang semakin menipis dipasar, jadi terpaksa harus dibeli.

\section{Citra Merek}

American Marketing Association mendefinisikan merek sebagai nama, istilah, tanda, lambang atau desain serta kombinasinya yang dimaksud untuk mengidentifikasikan barang atau jasa dari salah satu penjual atau kelompok penjual dan mendiferensiasikan dari para pesaing. Maka merek adalah produk atau jasa yang dimensinya mendiferensiasikan merek tersebut dengan beberapa cara dari produk atau jasa lainnya yang dirancang untuk memuaskan kebutuhan yang sama. Perbedaan ini bisa fungsional, rasional atau nyata berhubungan dengan kinerja dari merek. Perbedaan ini bisa juga lebih bersifat simbolis, emosional, atau tidak nyata berhubungan dengan apa yang direpresentasikan merek (Kotler dan Keller, 2009:258). Pengertian merek menurut Kotler dan Gary dalam Alma (2010:147):

1. Merek adalah sebuah nama, istilah, tanda, simbol atau desain atau kombinasinya yang bertujuan untuk mengidentifikasi barang dan jasa yang membedakan suatu produk dengan produk saingan.

2. Nama cap adalah bagian dari cap yang dapat diucapkan. Biasanya ini menunjukkan nama perusahaannya.

3. Merek cap ialah bagian dari cap yang dapat dikenal atau diketahui, tetapi tidak dapat diucapkan, misalnya simbol-simbol, lambang,logo, desain, atau bentuk-bentuk spesifik huruf atau warna.

4. Cap dagang ialah cap atau bagian dari cap yang memberikan perlindungan hukum, melindungi hakhak pemilik merek atau cap.

Tjiptono (2011:112) mendefinisikan citra merek yakni deskripsi tentang asosiasi dan keyakinan konsumen terhadap merek tertentu. Sedangkan citra merek menurut Setiadi (2003:180) citra merek merupakan representasi dari keseluruhan persepsi terhadap merek dan dibentuk dari informasi dan pengalaman masa lalu terhadap merek itu. Citra terhadap merek berhubungan dengan sikap yang berupa keyakinan dan preferensi terhadap suatu merek. Konsumen yang memiliki citra yang positif terhadap suatu merek, akan lebih memungkinkan untuk melakukan pembelian. Salinas dan Pérez (2009:6) merumuskan indikator yang dapat mengukur citra merek, yaitu sebagai berikut:

1. Produk-produk dari merek dikenal memiliki kualitas tinggi.

2. Produk-produk dari merek dikenal memiliki karakteristik yang lebih baik dari pesaing.

3. Produk-produk dari merek pesaing biasanya lebih murah.

4. Merek dikenal bagus.

5. Merek memiliki kepribadian yang membedakan dirinya dari pesaing. 
6. Merek tidak pernah mengecewakan pelanggan.

7. Merek merupakan salah satu merek terbaik di sektornya.

8. Merek sangat kuat di pasar.

\section{Minat Beli}

Konsumen dalam keseharian kehidupannya selalu berbelanja apa saja yang mereka butuhkan, mulai dari komoditi yang sangat diperlukan sampai ke barang yang sebetulnya kurang diperlukan tapi dibeli juga. Semua perilaku ini tentu ada yang mempengaruhinya, baik secara rasional ataupun emosional. Sebelum konsumen mengambil keputusan untuk membeli suatu barang, ada beberapa faktor stimulus yang mempengaruhi. Stimulus datang dari informasi mengenai produk, harga, lokasi dan promosi, serta ditambah bukti fisik, orang-orang, dan proses untuk pemasaran jasa. Calon konsumen dipengaruhi oleh stimulus ini, kemudian dengan mempertimbangkan faktor lain seperti keuangan, budaya, teknologi, maka masuklah segala informasi tersebut ke dalam black box konsumen. Konsumen mengolah segala informasi tersebut dan diambillah kesimpulan berupa respons yang muncul produk apa yang dibeli, merek, toko atau dealer, serta waktu kapan untuk membeli dan sebagainya.

Sikap pembelian konsumen sering kali diawali dan dipengaruhi oleh banyaknya rangsangan (stimulus) dari luar dirinya, baik berupa rangsangan pemasaran maupun rangsangan dari lingkungannya. Rangsangan tersebut kemudian diproses dalam diri sesuai dengan karakteristik pribadinya, sebelum akhirnya diambil keputusan pembelian. Karakteristik pribadi konsumen yang dipergunakan untuk memproses rangsangan tersebut sangat kompleks, dan salah satunya adalah motivasi konsumen untuk membeli.

Minat digambarkan sebagai suatu situasi seseorang sebelum melakukan suatu tindakan, yang dapat dijadikan dasar untuk memprediksi perilaku atau tindakan tersebut. Minat beli merupakan perilaku yang muncul sebagai respons terhadap objek yang menunjukkan keinginan pelanggan untuk melakukan pembelian (Kotler, 2009:15). Minat beli merupakan tahap kecenderungan konsumen untuk bertindak sebelum keputusan membeli benar-benar dilaksanakan. Terdapat perbedaan antara pembelian aktual dan minat pembelian. Bila pembelian aktual adalah pembelian yang benar-benar dilakukan oleh konsumen, maka minat pembelian adalah niat untuk melakukan pembelian pada kesempatan mendatang (Kinnear dan Taylor dalam Bachriansyah, 2011). Menurut Swastha dalam Winahyu (2012), minat beli merupakan perilaku konsumen yang menunjukkan sejauh mana komitmennya untuk melakukan pembelian. Kebutuhan dan keinginan konsumen akan barang dan jasa berkembang dari masa ke masa dan mempengaruhi perilaku mereka dalam pembelian produk. Minat beli dapat diidentifikasi melalui indikator-indikator sebagai berikut (Ferdinand, 2002:129):

1. Minat transaksional, yaitu kecenderungan seseorang untuk membeli produk.

2. Minat referensial, yaitu kecenderungan seseorang untuk mereferensikan produk kepada orang lain.

3. Minat preferensial, yaitu minat yang menggambarkan perilaku seseorang yang memiliki preferensi utama pada produk tersebut. Preferensi ini hanya dapat diganti jika terjadi sesuatu dengan produk preferensinya.

4. Minat eksploratif, minat ini menggambarkan perilaku seseorang yang selalu mencari informasi mengenai produk yang diminatinya dan mencari informasi untuk mendukung sifat-sifat positif dari produk tersebut.

\section{Kerangka Pemikiran}

Persepsi harga adalah bagaimana konsumen memandang harga suatu barang tertentu mengenai sesuai atau tidaknya harga dengan barang yang ditawarkan. Persepsi harga masing-masing konsumen bisa berbeda tergantung dari bagaimana seorang konsumen memberi penilaian pada suatu barang tertentu. Ketika memilih di antara beberapa merek, konsumen akan mengevaluasi dan membandingkan dengan standar harga sebagai referensi untuk melakukan pembelian. 
Desyani, E.

Citra merek adalah pandangan dan keyakinan konsumen terhadap merek tertentu. Citra merek berasal dari reputasi perusahaan dan produk-produk yang diciptakan oleh perusahaan tersebut. Citra juga tercipta dari keseluruhan persepsi konsumen mengenai segala sesuatu yang melekat dengan suatu merek. Jika citra perusahaan baik di mata konsumen, maka akan lebih memungkinkan timbul minat di benak konsumen yang nantinya akan melakukan pembelian.

Minat beli merupakan perilaku konsumen sebelum melakukan keputusan pembelian yang diawali dengan keinginan dan ketertarikan terhadap suatu barang. Minat beli muncul dari berbagai stimulus baik dari dalam diri konsumen sendiri seperti rasa ketertarikan, keingintahuan, dan keinginan maupun faktor dari luar seperti rekomendasi dari orang lain.

Berdasarkan uraian di atas, serta mengacu pada permasalahan dalam penelitian ini, dibuatlah suatu kerangka pemikiran dalam bentuk sebagaimana terpapar pada gambar di bawah ini.

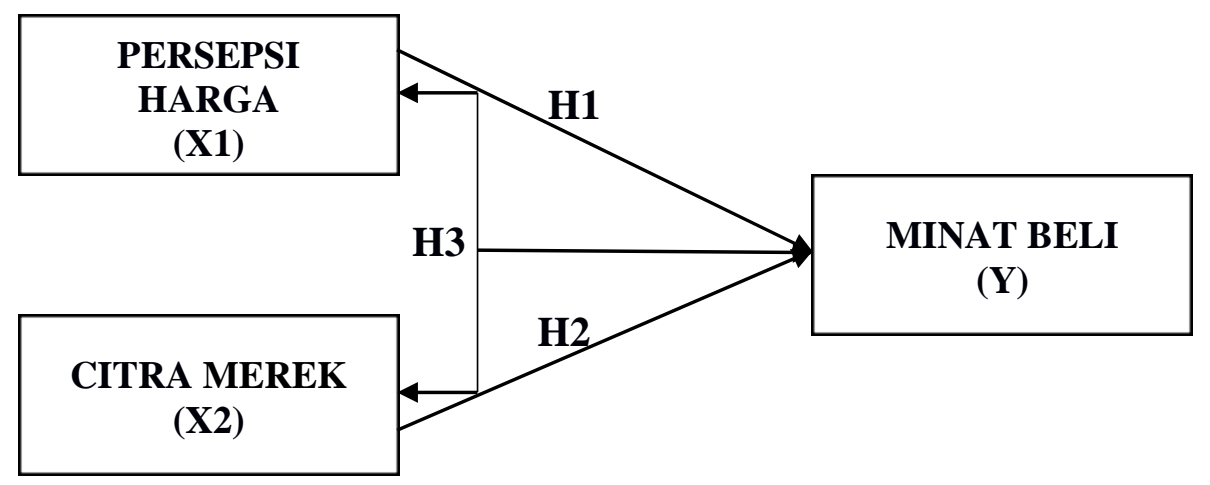

Gambar 1 Kerangka Pemikiran

\section{Hipotesis}

Berdasarkan permasalahan dan kerangka pemikiran yang dikemukakan, maka dapat disusun hipotesis penelitian sebagai berikut:

1. Persepsi harga berpengaruh signifikan terhadap minat beli produk motor merek Yamaha NMAX di Kota Palu.

2. Citra merek berpengaruh signifikan terhadap minat beli produk motor merek Yamaha NMAX di Kota Palu.

3. Persepsi harga dan citra merek berpengaruh secara signifikan terhadap minat beli produk motor merek Yamaha NMAX di Kota Palu.

\section{METODE PENELITIAN}

Sesuai dengan perumusan masalah dan tujuan penelitian, jenis penelitian yang digunakan adalah penelitian studi kasus yang berupa penelitian penjelasan (explanatory research). Menurut Singarimbun, Masri dan Effendi (2008:5) penelitian penjelasan adalah penelitian yang menyoroti hubungan kausal antara variabel-variabel penelitian dan menguji hipotesis yang telah dirumuskan sebelumnya. Adapun ruang lingkup penelitian ini adalah menganalisis pengaruh persepsi harga dan citra merek terhadap minat beli produk motor merek Yamaha NMAX di kota Palu serta berlokasi di kota Palu.

Populasi yang akan diteliti dari penelitian ini adalah seluruh masyarakat kota Palu yang mengetahui dan belum memiliki serta berminat pada motor Yamaha NMAX. Menurut Sugiyono (2014:49) populasi adalah wilayah generalisasi yang terdiri atas objek/subjek yang mempunyai kualitas atau karakteristik tertentu yang ditetapkan oleh peneliti untuk dipelajari dan kemudian ditarik kesimpulannya. Selanjutnya menurut Sugiyono (2015:62) sampel adalah bagian dari jumlah dan 
karakteristik yang dimiliki oleh populasi. Sampel yang diambil harus betul-betul representatif (mewakili). Pengambilan sampel dalam penelitian ini menggunakan teknik non probability sampling yaitu teknik purposive sampling, yaitu teknik pengambilan sampel untuk tujuan tertentu saja dan dilakukan berdasarkan kriteria tertentu yang ada pada responden (Sugiyono, 2015). Purposive sampling menurut Tungga, Saputra dan Vijaya (2014:84) adalah teknik pengambilan sampel dengan menggunakan pertimbangan tertentu. Pemilihan teknik ini dilakukan karena mungkin saja peneliti telah memahami bahwa informasi yang dibutuhkan dapat diperoleh dari satu kelompok sasaran tertentu yang mampu memberikan informasi yang dikehendaki karena mereka memang memiliki informasi seperti itu dan mereka memenuhi kriteria yang ditentukan oleh peneliti.

Kriteria sampel yang digunakan dalam penelitian ini meliputi: responden tinggal di kota Palu, berusia minimal 20 tahun, mengetahui produk motor merek Yamaha NMAX, dan belum memiliki motor merek Yamaha NMAX. Penentuan jumlah sampel dalam penelitian ini merujuk pada Teori Roscoe dalam Sugiyono (2013:130) yaitu minimal 10 kali dari jumlah variabel yang diteliti (variabel independen + variabel dependen). Penelitian ini terdiri dari 2 variabel independen (persepsi harga dan kualitas produk) dan 1 variabel dependen (minat beli). Berdasarkan pertimbangan tersebut maka jumlah sampel adalah $30 \times 3=90$ responden.

Data yang digunakan dalam penelitian ini terdiri dari data primer dan data sekunder. Data primer bersumber dari penyebaran kuesioner secara langsung kepada peminat produk motor Yamaha NMAX di kota Palu di mana hasil dari data tersebut dikumpulkan dan diolah sendiri oleh peneliti. Data sekunder bersumber dari studi pustaka melalui buku, berbagai jurnal, artikel pemasaran, maupun artikel yang diambil dari internet yang berhubungan dengan penelitian. Untuk memudahkan dalam pengumpulan data yang diperlukan dalam penelitian ini, dilakukan teknik pengumpulan data sebagai berikut:

1. Dokumentasi adalah mencari data mengenai hal-hal atau variabel penelitian yaitu persepsi harga, citra merek dan minat beli yang dapat berupa catatan, buku, majalah dan lain sebagainya.

2. Kuesioner adalah daftar pertanyaan tertulis yang telah dirumuskan sebelumnya. Kuesioner dibuat dengan menggunakan pertanyaan terbuka, yaitu terdiri dari pertanyaan-pertanyaan untuk menjelaskan identitas responden, dan pertanyaan tertutup, yaitu pertanyaan yang meminta responden untuk memilih salah satu jawaban yang tersedia dari setiap pertanyaan mengenai persepsi harga dan citra merek terhadap minat beli produk motor merek Yamaha NMAX.

3. Interview, yaitu pengumpulan data yang diperoleh melalui wawancara langsung kepada responden mengenai produk dan minat responden terhadap produk motor merek Yamaha NMAX.

\section{HASIL DAN PEMBAHASAN}

\section{HASIL PENELITIAN}

Hasil analisis regresi linear berganda dari penelitian ini akan disajikan pada tabel di bawah ini:

Tabel 2 Hasil Analisis Regresi Linear Berganda

\begin{tabular}{|l|c|c|l|c|c|}
\hline \multirow{2}{*}{ Model } & \multicolumn{2}{|c|}{$\begin{array}{c}\text { Unstandardiezed } \\
\text { Coefficient }\end{array}$} & $\begin{array}{c}\text { Standardized } \\
\text { Coefficients }\end{array}$ & \multirow{2}{*}{ t } & \multirow{2}{*}{ Sig. } \\
\cline { 2 - 5 } & B & Std. Error & Beta & & \\
\hline (Constan) & 1.446 & .304 & & 4.751 & .000 \\
\hline Persepsi Harga (X1) & 0.154 & .074 & 0.180 & 2.079 & .041 \\
\hline Citra Merek (X2) & 0.464 & .072 & 0.576 & 6.465 & .000 \\
\hline R square (r $\left.{ }^{2}\right)$ & $=0.468$ & & F Hitung & $=38.285$ & \\
Adjusted R square & .456 & Constanta & $=$ & 1.446 & \\
Multiple R & $=.684$ & Sig. F & $=0.000$ & \\
\hline
\end{tabular}


Berdasarkan nilai pada Tabel 2 jika ditulis dalam bentuk persamaan regresi linear berganda dapat dijabarkan sebagai berikut:

$$
\mathrm{Y}=1,446+0,154 \mathrm{X} 1+0,464 \mathrm{X} 2
$$

Berdasarkan bentuk penjabaran tersebut, menunjukkan variabel independen yang di analisis (X1 dan X2) memberi pengaruh yang positif terhadap variabel dependen (Y)

1. Nilai Konstanta sebesar 1,446, artinya jika variabel independen (persepsi harga) bernilai 0 , maka variabel dependen (minat beli produk motor merek Yamaha NMAX di kota Palu) nilainya sebesar 1,446 .

2. Dilihat dari nilai Beta, variabel citra merek (X2) berpengaruh dominan terhadap variabel minat beli (Y) karena variabel tersebut memiliki nilai Beta terbesar yaitu, 0.576, sehingga dapat disimpulkan bahwa citra merek merupakan variabel yang paling besar pengaruhnya terhadap minat beli produk motor merek Yamaha NMAX di kota Palu.

3. Koefisien regresi variabel persepsi harga (X1) sebesar 0,154 , artinya jika persepsi harga naik 1 , maka minat beli produk motor merek Yamaha NMAX di kota Palu naik sebesar 0,154.

4. Koefisien regresi variabel citra merek (X2) sebesar 0,464, artinya jika citra merek naik 1 , maka minat beli produk motor merek Yamaha NMAX di kota Palu naik sebesar 0.464.

Berdasarkan Tabel 1 rekapitulasi juga dapat dilihat pengaruh hasil uji determinasi R Square (R2) sebesar 0.468. Nilai tersebut dapat menunjukkan bahwa seluruh variabel independen (X1 dan X2) mempunyai kontribusi secara bersama-sama sebesar $46,8 \%$. terhadap variabel dependen yaitu minat beli. Sedangkan sisanya $(100 \%-46,8 \%=53,2 \%)$, dipengaruhi oleh variabel lain yang tidak diteliti. Adapun tingkat keeratan hubungan antara variabel-variabel independen yaitu persepsi harga dan citra merek terhadap variabel dependen yaitu minat beli produk motor merek Yamaha NMAX di kota Palu, dapat dilihat melalui nilai Multiple $R$ sebesar 0,684 yang berarti memiliki tingkat hubungan yang kuat. Hasil tersebut menunjukkan bahwa secara keseluruhan variabel independen berhubungan kuat terhadap variabel dependen. Adapun pedoman untuk memberikan interpretasi koefisien korelasi menurut Sugiyono, (2014:184) sebagai berikut:

Tabel 3 Interprestasi koefesien Korelasi

\begin{tabular}{|c|c|}
\hline Interval Koefesien & Tingkat Hubungan \\
\hline $0,00 \quad-\quad 0,199$ & Sangat rendah \\
\hline $0,20-0,399$ & Rendah \\
\hline $0,40 \quad-\quad 0,599$ & Sedang \\
\hline $0,60-0,799$ & Kuat \\
\hline $0,80-1,000$ & Sangat kuat \\
\hline
\end{tabular}

\section{Hasil Pengujian Hipotesis \\ Hasil Uji t Variabel Persepsi Harga}

Hasil pengujian seperti yang terlihat pada tabel rekapitulasi regresi linear berganda di atas, menunjukkan variabel persepsi harga memiliki nilai signifikansi 0,041 , artinya nilai tersebut lebih kecil dari taraf signifikansi yang disyaratkan $\alpha 0,05$. Maka dapat disimpulkan bahwa secara parsial 
variabel persepsi harga berpengaruh signifikan terhadap minat beli produk motor merek Yamaha NMAX di kota Palu dengan nilai koefisien regresi sebesar 0,154.

\section{Hasil Uji t Variabel Citra Merek}

Hasil pengujian seperti yang terlihat pada tabel rekapitulasi regresi linear berganda di atas, menunjukkan variabel citra merek memiliki nilai signifikansi 0,000 artinya nilai tersebut lebih kecil dari taraf signifikansi yang disyaratkan $\alpha 0,05$. Maka dapat disimpulkan bahwa secara parsial variabel citra merek berpengaruh signifikan terhadap minat beli produk motor merek Yamaha NMAX di kota Palu dengan nilai koefisien regresi sebesar 0,464.

\section{Hasil Uji F}

Uji F digunakan untuk membuktikan hipotesis awal yaitu Persepsi harga dan citra merek berpengaruh secara signifikan terhadap minat beli produk motor merek Yamaha NMAX di kota Palu. Nilai sig F menujukan angka 0,000, artinya nilai tersebut lebih kecil jika dibandingkan dengan nilai sesuai ketentuan $\mathrm{t} \alpha 0,05$ dengan demikian variabel persepsi harga dan citra merek berpengaruh signifikan terhadap minat beli produk motor merek Yamaha NMAX di kota Palu.

\section{PEMBAHASAN}

\section{Pengaruh Persepsi Harga terhadap Minat Beli Produk Motor Merek Yamaha NMAX}

Malik dan Yaqoob (2012:487) mengatakan bahwa persepsi harga adalah sebuah proses di mana pelanggan menafsirkan nilai harga dan atribut ke barang atau pelayanan yang diinginkan. Bagaimana seseorang memandang harga suatu barang (tinggi, rendah atau wajar) akan mempengaruhi minat untuk membeli barang tersebut. Hasil pengujian penelitian ini menunjukkan bahwa variabel persepsi harga (X1) memberikan pengaruh positif terhadap minat beli produk motor merek Yamaha NMAX di kota Palu. Hal ini sejalan dengan penelitian terdahulu yang dilakukan oleh Joel, Massie dan Sepang (2014), yang menyatakan bahwa motivasi, persepsi harga, dan kualitas produk secara simultan dan parsial berpengaruh terhadap minat beli konsumen sepeda motor matic merek Yamaha MIO di kota Manado.

Harga Yamaha NMAX dinilai relatif terjangkau dilihat dari segi kualitas dan segudang spesifikasi handal yang dimiliki Yamaha NMAX, sehingga membuat konsumen merasa bahwa harga yang ditawarkan sudah sesuai. Harga yang lebih tinggi dibandingkan dengan motor matic pada umumnya bukan merupakan suatu masalah bagi konsumen karena Yamaha NMAX memiliki spesifikasi dengan fitur-fitur yang canggih dengan kualitas yang jauh lebih baik yang menjamin kenyamanan dan keselamatan pengendara. Selain itu, faktor prestise atau gengsi juga mempengaruhi konsumen untuk beranggapan bahwa dengan mengendarai Yamaha NMAX dapat menambah rasa percaya diri karena Yamaha NMAX merupakan motor matic yang berkelas. Hal ini menandakan bahwa konsumen sangat memperhatikan kualitas, manfaat serta prestise dari suatu produk jika dilihat dari harga produk tersebut. Sehingga dalam penelitian ini secara statistik variabel persepsi harga (X1) berpengaruh secara signifikan terhadap variabel minat beli produk motor merek Yamaha NMAX di kota Palu.

\section{Pengaruh Citra Merek terhadap Minat Beli Produk Motor Merek Yamaha NMAX}

Setiadi (2003:180) menyatakan citra merek merupakan representasi dari keseluruhan persepsi terhadap merek dan dibentuk dari informasi dan pengalaman masa lalu terhadap merek itu. Citra merek yang baik dari suatu barang akan memberikan kesan yang baik pula di benak konsumen. Minat beli dapat timbul ketika konsumen mendapatkan informasi mengenai suatu barang yang dinilai bagus oleh orang-orang di sekitarnya atau informasi dari berbagai media serta dapat pula berasal dari pengalaman pribadi yang pernah menggunakan atau mengonsumsi suatu barang.

Hasil pengujian penelitian ini menunjukkan bahwa variabel citra merek (X2) memberikan pengaruh positif terhadap minat beli produk motor merek Yamaha NMAX di kota Palu. Hal ini sejalan dengan penelitian terdahulu yang dilakukan oleh Pujadi (2010), yang menyatakan bahwa citra merek dapat ditingkatkan dengan meningkatkan persepsi kualitas dan kualitas pesan iklan. Kemudian, citra merek 
Desyani, E.

yang semakin tinggi akan mempengaruhi sikap terhadap merek dan selanjutnya meningkatkan minat beli pasta gigi Ciptadent.

Berdasarkan penelitian ini, Yamaha NMAX memiliki citra merek yang positif di benak konsumen. Konsumen yang mengenal merek Yamaha NMAX mengetahui bahwa produk ini memiliki kualitas yang tidak diragukan, spesifikasi yang lengkap serta memiliki nilai prestise atau gengsi bagi pengendara karena merupakan produk yang berkelas. Yamaha NMAX merupakan produk motor matic yang berbeda dengan produk motor matic keluaran Yamaha sebelumnya. Ciri khas dari produk ini adalah dimensi bodi yang besar khas skutik moge yang terlihat lebih gagah di bandingkan dengan motor matic Yamaha sebelumnya.

Yamaha NMAX memiliki kepribadian yang membedakannya dengan pesaingnya yaitu Honda PCX, baik dari segi tampilan yang lebih mewah dan sporty sehingga cocok digunakan untuk segala usia, maupun dari spesifikasi dan fitur-fitur lengkap yang dimilikinya. Penetapan harga yang jauh lebih murah, Yamaha NMAX memiliki keunggulan yang tidak kalah bersaing dengan Honda PCX. Berdasarkan penelitian ini, konsumen beranggapan bahwa Yamaha NMAX tidak pernah mengecewakan pelanggan, karena kualitas dan spesifikasinya sesuai dengan apa yang dijanjikan.

Yamaha NMAX juga merupakan salah satu produk terbaik di sektor industri otomotif Indonesia, khususnya untuk sepeda motor jenis skuter matic, walaupun masih termasuk produk yang terbilang baru di dunia otomotif Indonesia. Citra merek yang terkenal baik membuat merek ini termasuk merek yang namanya cukup kuat di pasar otomotif Indonesia. Hal-hal inilah yang membuat Yamaha NMAX banyak menarik minat pencinta otomotif di tanah air dan menjadikan pertimbangan konsumen sebelum melakukan pembelian. Sehingga dalam penelitian ini, secara statistik variabel citra merek (X2) berpengaruh secara signifikan terhadap variabel minat beli produk motor merek Yamaha NMAX di kota Palu.

\section{KESIMPULAN DAN SARAN}

\section{Kesimpulan}

Berdasarkan hasil pembahasan penelitian yang telah dijabarkan di atas, maka penulis mengambil beberapa kesimpulan dari hasil penelitian yang telah dilakukan ini sebagai berikut:

1. Persepsi harga dan citra merek secara serempak berpengaruh terhadap minat beli produk motor merek Yamaha NMAX Di kota Palu.

2. Persepsi harga terbukti secara parsial berpengaruh signifikan terhadap terhadap minat beli produk motor merek Yamaha NMAX Di kota Palu.

3. Citra merek terbukti secara parsial berpengaruh signifikan terhadap minat beli produk motor merek Yamaha NMAX Di kota Palu.

\section{Saran}

Berdasarkan kesimpulan di atas maka peneliti memberikan beberapa saran mengenai pengaruh persepsi harga dan dan citra merek terhadap minat beli produk motor merek Yamaha NMAX di kota Palu sebagai bahan pertimbangan. Berikut beberapa saran tersebut.

1. Kepada pihak perusahaan dalam hal ini adalah Yamaha Indonesia Motor Manufacturing (YIMM) harus terus memperhatikan variabel persepsi harga khususnya indikator keterjangkauan harga untuk dapat menetapkan harga yang lebih terjangkau agar dapat bersaing dengan merek lain serta menambah minat beli konsumen terhadap produk motor merek Yamaha NMAX di kota Palu.

2. Diharapkan kepada PT. Yamaha Indonesia Motor Manufacturing (YIMM) untuk selalu mempertahankan kesesuaian harga dengan kualitas produk, karena merupakan indikator yang memiliki pengaruh tertinggi terhadap minat beli konsumen pada Yamaha NMAX di kota Palu.

3. Bagi peneliti selanjutnya yang ingin menjadikan sebagai referensi dapat mengombinasikan variabel-variabel lain yang mempengaruhi minat beli produk motor merek Yamaha NMAX di kota 
Palu di luar variabel persepsi harga dan citra merek yang juga dapat mempengaruhi minat beli konsumen, agar memperoleh hasil yang lebih maksimal dan memberikan kontribusi bagi pihak yang berkepentingan.

\section{REFERENSI}

Alma, Buchari. (2010). Kewirausahaan. Edisi Revisi, Bandung: Penerbit Alfabeta.

Bachriansyah, Rizky A. (2011). Analisis Pengaruh Kualitas Produk, Daya Tarik Iklan, dan Persepsi Harga Terhadap Minat Beli Konsumen Pada Produk Ponsel Nokia (Studi Kasus Pada Masyarakat di Kota Semarang), Skripsi Sarjana, Semarang: Fakultas Ekonomi Universitas Diponegoro.

Ferdinand, Augusty (2002). Metode Penelitian Manajemen. Semarang: Badan Penerbit Universitas Diponegoro.

Harjanti, Lily, Yurike Venesia (2015). Pengaruh Kualitas Layanan dan Persepsi Harga terhadap Kepuasan Pelanggan pada Maskapai Penerbangan Tiger Air Mandala. Jurnal. E-Journal WIDYA Ekonomika, Vol.1, No. 1, Oktober 2015 ISSN 2338-7808. Diakses pada 23 November 2016.

Kotler, Philip dan Kevin Lane Keller. (2009). Manajemen Pemasaran. Edisi Ke-13 Jilid I. Jakarta: Penerbit Erlangga.

Malik, Yaqoob, dan Aslam. (2012). The Impact of Price Perception, Service Quality, And Brand Image On Custumer Loyalty (Study Of Hospitality Industry In Pakistan Interdisciplinary. Journal Of Contempory Research In Business, Vol. 4, No. 5.

Peter, Paul J., Jerry C. Olson. (2010). Consumer Behavior \& Marketing Strategy. 9th Edition. Australia: McGraw Hill.

Pujadi, Bambang. (2010). Studi Tentang Pengaruh Citra Merek terhadap Minat Beli Melalui Sikap terhadap Merek. Tesis, Pasca Sarjana, Tak Diterbitkan. Semarang: Program Studi Magister Manajemen Program Pasca Sarjana Universitas Diponegoro.

Salinas, Eva Martínez dan Pérez, José Miguel Pina. (2009). Modeling the Brand Extensions' Influence on Brand Image. Journal of Business Research. Januari 2009, No. 62, Hal. 50-60. Diakses pada 9 Maret 2017.

Schiffman, L.G dan Kanuk, L.L. (2004). Cosumer Behavior. United States of America: Pearson Prentice Hall.

Selang, Christian A.D. (2013). Bauran Pemasaran (Marketing Mix) Pengaruhnya terhadap Loyalitas Konsumen pada Fresh Mart Bahu Mall Manado. Jurnal EMBA, Vol. 1, No.3, juni 2013. Diakses pada 9 Maret 2017.

Setiadi, J. Nugroho. (2003). Perilaku Konsumen Konsep dan Implikasi untuk Strategi dan Penelitian Pemasaran. Jakarta: Kencana.

Simamora, Bilson. (2002). Panduan Riset Perilaku Konsumen. Jakarta: Gramedia.

Singarimbun, Masri dan Sofian Effendi. (2008). Metode Penelitian Survai. Edisi Revisi. Jakarta: Penerbit LP3ES.

Solomon, Michael R. (2007).Consumer Behavior (Edisi Tujuh). United States of America: Pearson Prentice Hall.

Sugiyono. (2013). Metode Penelitian Kuantitatif Kualitatif dan R\&D. Bandung: Alfabeta

Sugiyono. (2014). Memahami Penelitian Kualitatif. Cetakan Ke-10. Bandung: Alfabeta

Sugiyono. (2015). Statistika Untuk Penelitian. Cetakan Ke-26. Bandung: Alfabeta.

Sumarwan, Ujang. (2003). Perilaku Konsumen. Jakarta: Ghalia Indonesia.

Tjiptono, Fandy. (2011). Manajemen \& Strategi Merek. Yogyakarta: Penerbit Andi.

Tungga, Wikrama Ananta, Komang Adi Kurniawan Saputra dan Diola Prameswari Vijaya. (2014).

Metodologi Penelitian Bisnis. Cetakan Ke-1. Yogyakarta: Penerbit Graha Ilmu. 
Desyani, E.

Winahyu, Dasanti Jiwaning. (2012). Analisis Pengaruh Persepsi Harga, Kualitas Produk dan Daya Tarik Iklan Terhadap Minat Beli Air Minum Axogy (Studi Kasus Pada Pengguna Air Minum Kota Magelang Jawa Tengah), Skripsi Sarjana, Tidak Diterbitkan. Semarang: Fakultas Ekonomika dan Bisnis Universitas Diponegoro. 